\title{
Cation Channels in Erythrocytes - Historical and Future Perspective
}

\author{
Lars Kaestner*
}

Institute for Molecular Cell Biology, Medical Faculty, Saarland University, 66421 Homburg/Saar, Germany

\begin{abstract}
Compared to ion pumps and carriers, ion channels have been quite late recognised as individual transport identities in red blood cells. Here the transition from cell population based flux experiments to single cell based patchclamp investigations are described in detail. The present knowledge of cation channels in red blood cells from their molecular identity to their electrophysiological properties are summarised. Tendencies and novel concepts for future research concerning ion-transport across the red blood cell membrane are discussed.
\end{abstract}

Keywords: Red blood cells, calcium homeostasis, cation flux, electrophysiology, patch-clamp.

\section{INTRODUCTION}

Cation channels are versatile transporters, responsible for the adjustment of the resting membrane potential in most cells, for the induction of the action potential in excitable cells and the transmembrane transduction of many signalling cascades and ion-exchange in general. Historically, methods of tracer flux experiments using red blood cells have been extremely popular for investigating transmembrane transport processes (e.g. [1,2]). The major reasons for this popularity are summarised in Box 1.

\begin{tabular}{|c|c|}
\hline (i) & $\begin{array}{c}\text { availability (also in large numbers) without seriously affecting the } \\
\text { donor - such they are the easiest available living cells from } \\
\text { humans }\end{array}$ \\
\hline (ii) & $\begin{array}{c}\text { individual cells (not connected as in tissue), so if the surrounding } \\
\text { medium is changed they are immediately and completely covered } \\
\text { by the new medium }\end{array}$ \\
(iii) & $\begin{array}{c}\text { especially mammalian red blood cells do not contain cell } \\
\text { organelles or subcellular compartments (cp. Fig. 1A) that could be } \\
\text { used as ion stores }\end{array}$ \\
\hline (iv) & $\begin{array}{c}\text { the cellular population seems very homogeneous, cell to cell } \\
\text { differences are minor since growth and development are almost } \\
\text { stagnating in red blood cells. }\end{array}$ \\
\hline
\end{tabular}

Box 1. Reasons for popularity of red blood cells in investigating transmembrane transport processes.

Even nowadays the availability (reason (i) in Box 1), especially the aspect of using human cells, holds a strong argument. Nevertheless, a decent number of studies have been performed on animal red blood cells. In the following the reasons for using animal cells are discussed:

a) the size of the cells - it is not by chance that the first microscopically observed cells at all (probably around 1660) have been frog red blood cells [3]. For an illustration of differing cell sizes refer to Fig. (1A);

b) to avoid the special condition of lacking cell organelles and sub-cellular structures (argument (iii) in

*Address correspondence to this author at the Institute for Molecular Cell Biology, Medical Faculty, Saarland University, 66421 Homburg/Saar, Germany; Tel: +49 68411626 103; Fax: +49 6841 1626104; E-mail: dr.lars.kaestner@uniklinikum-saarland.de
Box 1) by investigating red blood cells of e.g. birds or amphibians, that contain a few organelles like a nucleus or mitochondria and are therefore more representative for cells in general;

c) disease models might be more advantageous on certain animals, for instance the malaria Plasmodium gallinaceum in chicken red blood cells (cp. Fig. (1B) and Thomas et al. 2001 [4]) is not infectious to humans and therefore eases cell handling;

d) animal red blood cells may display certain properties that are absent or not inducible in human red blood cells - examples are transgenic animals or lamprey erythrocytes having an inactive band 3 protein $[5,6]$.

Within this review the focus is set to human red blood cells, however, animal red blood cells are covered if their investigation made a significant contribution to the cation channel identification or investigation.

With the advent of methods addressing membrane properties more directly than flux experiments, namely the patch-clamp technique, but also single molecule imaging techniques or cloning and over-expressions of channels e.g. in oocytes, on the one hand a lot of open questions in the field of red blood cell transmembrane transport could be resolved (see below). On the other hand other cell types, not meeting the conditions of being individual cells per se and not containing cell organelles (reasons (ii) and (iii) in Box 1, respectively), became easier to investigate and ousted red blood cells somewhat from their central role of transport investigations. However, in the recent years it became evident, that the homogeneous cell population (argument (iv) in Box 1) is of limited validity. There are subpopulations behaving different from the rest of the cells indicating that red blood cells are much more versatile than one would expect from membrane-bags just holding the haemoglobin.

\section{THE DISCOVERY OF CATION CHANNELS IN ERYTHROCYTES: FROM FLUX-MEASUREMENTS TO ELECTROPHYSIOLOGY}

The transport mediated by the cation channels in the red blood cell membrane was in the major fraction observed 

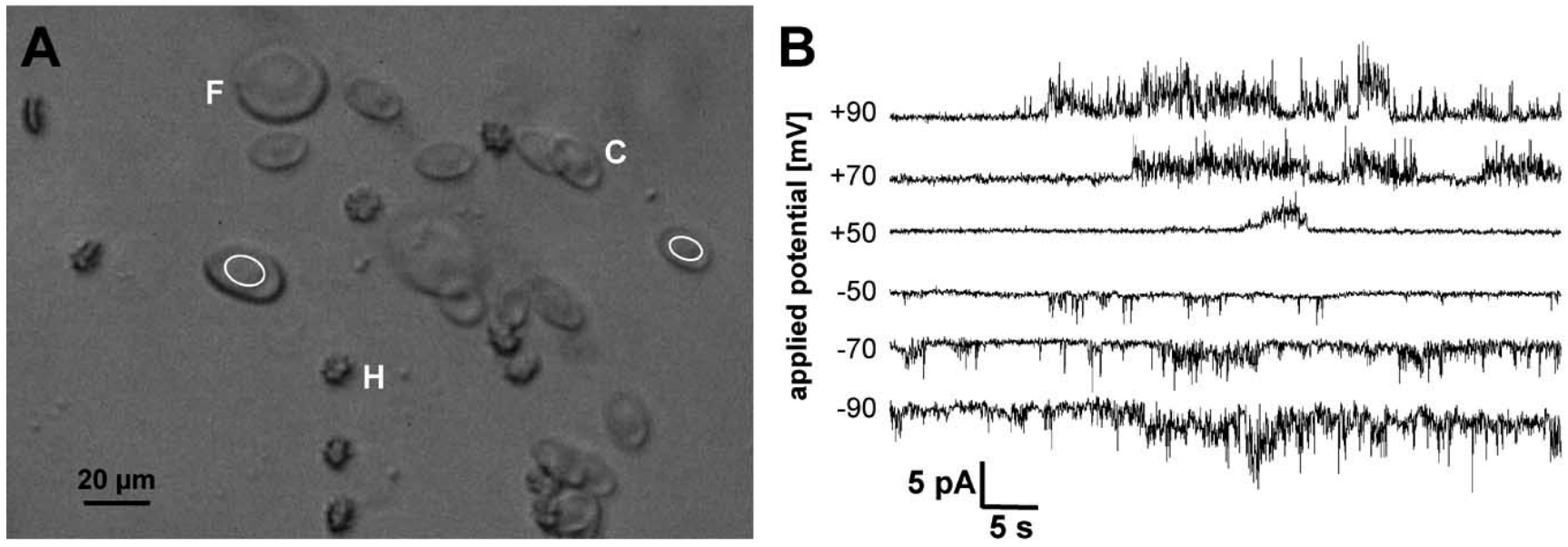

Fig. (1). Red blood cells of several species. The image A provides a white light image comparing red blood cells from frogs (F) chicken (C) and human $(\mathrm{H})$. B depicts one of the first current-traces measured in malaria-infected (Plasmodium gallinaceum) chicken red blood cells. Recordings in cell-attached configuration, identical pipette and bath solution containing in $\mathrm{mM}: 150 \mathrm{NaCl}, 5 \mathrm{KCl}, 1.4 \mathrm{CaCl}_{2}, 1 \mathrm{MgCl}_{2}, 5$ glucose, 10 HEPES, pH adjusted to 7.4. Figure 1B modified from Kaestner 2001 [71].

before ion channels were established facts of life [7]. However, the discovery of cation transport across a biological membrane in general and across red blood cell membranes was a long way. The earliest observations considering cation concentration alterations under certain conditions date back more than 100 years e.g. Abderhalden 1898 [8] and Bang 1909 [9].

The investigations measuring real transport across a membrane were boosted by the discovery of radioactivity, allowing a precise measurement of the movement of radioisotopes across red blood cell membranes. Among the first papers proving a cation permeability of the membrane under physiological conditions were the experiments by Elma and Waldo Cohn published in 1939 [10]. ${ }^{24} \mathrm{NaCl}$ was intravenously injected into dogs and blood samples were examined after several hours in vitro or in vivo. Considerably amounts of ${ }^{24} \mathrm{Na}$ were found inside erythrocytes proving a Na-permeability. The radioactive tracer flux measurements became state of the art and the predominant technique in investigating ion transport for almost 50 years. Such measurements based on observations in cell populations have detected general principles. However, such approaches are hardly be able to identify special transport properties of a minor subpopulation of the cells. The state of knowledge concerning passive cation transport in the red blood cell membrane at the advent of the cellular electrophysiology is comprehensively summarised by Lew and Beaugé [11].

The investigations "predicting" the Gardos-channel date back to the 1930s when Ørskov measured a $\mathrm{K}^{+}$loss caused by $\mathrm{Pb}^{2+}[12]$ and Wilbrandt, who detectet $\mathrm{K} \mathrm{K}^{+}$efflux upon inhibition of glycolysis [13]. Both investigations did not even hypothesise the $\mathrm{Ca}^{2+}$-activated $\mathrm{K}^{+}$-channel, but the $\mathrm{K}^{+}$fluxes they measured were caused by exactly that channel. However, the transport process as an $\mathrm{Ca}^{2+}$-activated $\mathrm{K}^{+}$pathway was demonstrated by Gardos [14] and the effect named after him - later on for consistence the channel was also called Gardos-channel. However, in the 1970s novel electrophysiological methods appeared, revolutionising the investigations and the understanding of membrane transport in general. As one of the precurser of the patch clamptechnique the micro-electrode methodology appeared. In the 1970s this was applied on Amphiuma red blood cells because of their enormous size exceeding even the size of frog red blood cells (cp. Fig. 1A). It was shown that the hyperpolarisation occuring with the micropuncture of the cells was $\mathrm{Ca}^{2+}$-dependent and determined by the membranes $\mathrm{K}^{+}$permability [15].

In similarity to the first observations of the Gardos channel the first results nowadays assigned to the voltageactivated non-selective cation channel, namely the experiments by Donlon and Rothstein from 1969 [16] were flux based. They found a three-phasic increase in the salt efflux from red blood cells with decreasing extracellular $\mathrm{NaCl}$ concentration and already discussed the hypothetical chance of a channel involvement. However, a voltage-activated cation channel was assigned to red blood cells by the work of Halperin et al. two decades later [17]. Remarkably it is a flux based paper giving evidence of a voltage-activated cation channel even after the establishment of the patch-clamp technique. The membrane potential was modulated by either varying the $\mathrm{K}^{+}$concentration gradient in the presence of valinomycin or by varying the concentration gradient of the permeant anion nitrate in the presence of $4,4^{6}$-diisothiocyanostilbene-2,2'-disulfonic acid (DIDS). Interestingly, this results could not be verified when the $\mathrm{Rb}^{+}$-flux was measured in solutions of low ionic strength (LIS) activating the channel by carbachol (see Fig. (2A) and P. Bennekou, personal communication).

It should be mentioned that parallel to the electrophysiological characterisation of the voltage-activated nonselective cation channel (see section 3 , below) a $\mathrm{K}^{+}\left(\mathrm{Na}^{+}\right) / \mathrm{H}^{+}$ exchanger was proposed and characterised [18, 19]. Both transport systems were assigned to be responsible for the residual $\mathrm{K}^{+}$and $\mathrm{Na}^{+}$fluxes in LIS solutions, but as pointed out before (Fig. 2A) under widely used LIS conditions the channel could not be observed in radioactive tracer flux experiments and most of the LIS effect is mediated by the $\mathrm{K}^{+}\left(\mathrm{Na}^{+}\right) / \mathrm{H}^{+}$exchanger. Only a portion of the initial flux 

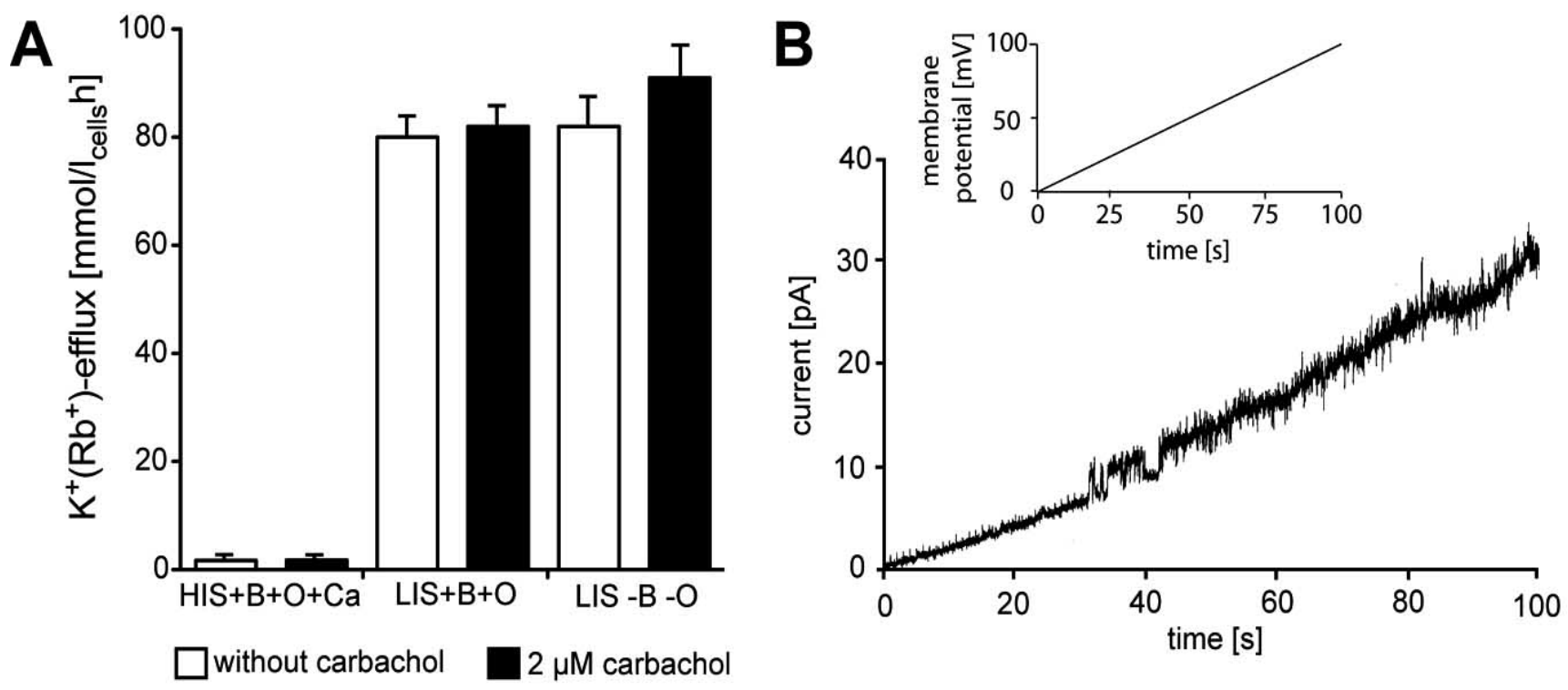

Fig. (2). Pannel A displays a radioactive tracer flux measurement. Each bar is the mean ( \pm SEM) of measurements from 3 independent blood samples from healthy donors. To address channel activity both major $\mathrm{K}^{+}$-transport entities, namely the $\mathrm{Na}^{+} / \mathrm{K}^{+} / 2 \mathrm{Cl}^{-}$-cotransporter and the $\mathrm{Na}^{+} / \mathrm{K}^{+}$-pump were inhibited with $100 \mu \mathrm{M}$ bumetanide (B) and $100 \mu \mathrm{M}$ ouabain (O), respectively. To be able to monitor an indirect channel activity (Gardos-channel mediated $\mathrm{K}^{+}$-efflux induced by $\mathrm{Ca}^{2+}$-influx), $2 \mathrm{mM} \mathrm{Ca}^{2+}$ was added to the external solution in the experiments performed in solutions of high ionic strength (HIS: $145 \mathrm{mM} \mathrm{NaCl}, 10 \mathrm{mM}$ MesTRIS, $10 \mathrm{mM}$ glucose). To depolarise the cells, measurements were performed in solution of low ionic strength (LIS: $10 \mathrm{mM}$ MesTRIS, $10 \mathrm{mM}$ glucose, $250 \mathrm{mM}$ sucrose) leading to a measured membrane potential of approximately $45 \mathrm{mV}$ [72]. Since carbachol activates the non-selective voltage activated cation channel [34], a significant difference should be observed in LIS-solutions in the presence and in the absence of carbachol. This change could not be measured. To ensure that bumetanide and ouabain do not interfere with the non-selective voltage activated cation channel, the experiments in LIS-solution were repeated without the presence of the mentioned inhibitors. Again, a significant difference between the presence and absence of carbachol was not detectable. Pannel B is a plot of a current trace recorded from an excised patch showing a number of biophysical properties of the non-selective voltage activated cation channel. The pipette and bath solution contained $20 \mathrm{mM}$ Na-tartrate and $70 \mathrm{mM}$ Na-tartrate, respectively. Additionally, both solutions contained $2.5 \mathrm{mM} \mathrm{BaCl} 2,10 \mathrm{mM}$ glucose, $100 \mu \mathrm{M}$ bumetanide, $100 \mu \mathrm{M}$ ouabain and $10 \mathrm{mM}$ MOPS. The tonicity of the solutions was adjusted to $300 \mathrm{mOsM}$ with sucrose and the pH-value was adjusted to 7.4 with $\mathrm{NaOH}$. The inset shows the applied voltage ramp in the voltage-clamp mode, while the current trace nicely reflects the open probability of the channel being zero up to a membrane potential of approximately $25 \mathrm{mV}$ and being about 1 from $75 \mathrm{mV}$ upwards. The conductance is approximately $21 \mathrm{pS}$ and the current-voltage relationship is within the range of the open probability roughly linear.

measured by Donlon and Rothstein, namely the second phase of the three-phasic increase is channel mediated [20, 21].

\section{CLASSIFICATION AND PROPERTIES OF CHANNELS ACHIEVED BY THE PATCH-CLAMP TECHNIQUE}

The patch-clamp technique as it was introduced by Neher, Sakmann and colleagues provided a tool for direct ion transport measurements through single channels and such provided a direct functional assay for a biophysical investigation of ion channels even allowing for versatile manipulation options. During the initial 20 years of patchclamp measurements on human red blood cells, investigations were limited to the cell-attached configuration and excised patches, where channels in the piece of membrane touched by the micropipette could be recorded, either with the rest of the cell between the two electrodes or under direct voltage control of the membrane, respectively. This is caused by the difficulty to achieve whole cell recordings from human red blood cells, due to their small size and the special shape, which is determined by the cytoskeleton [7]. In the early days of patch-clamping red blood cells, the possibility to achieve whole cell recordings on human red blood cells was thought to be impossible [22]. However, with the establishment of automatised pipette pullers, whole cell recordings on red blood cells became a routine method.

The first person investigating ion channels in red blood cells was Hamill, who published current traces in an abstract [23] clearly depicting single channel openings of the Gardoschannel giving a single channel conductance of $18 \mathrm{pS}$. This initial report was followed by a comprehensive chapter about „Potassium and Chloride Channels in Red Blood Cells“ in the 1st edition of the classic "Single Channel Recording“ book edited by Sakmann and Neher [24]. This chapter was focusing on frog red blood cells, but contained all classical patch-clamp approaches including whole cell recordings. The first comprehensive analysis of the Gardos channel in human red blood cells was performed by Grygorczyk and Schwarz [25] revealing basic properties such as the $\mathrm{K}^{+}$to $\mathrm{Na}^{+}$selectivity of 15:1, inward rectification and an estimation of (in average) 10 channels per cell. After this initial report a number of follow-up paper appeared correlating the patch-clamp data to the flux measurements [26] and further characterising the Gardos-channel (cp. Table 1). The following years more detailed reports were published, e.g. [27, 28] 
culminating in two papers by Leinders et al. [29, 30] summarising and complementing the knowledge of the opening behaviour of the Gardos channel.

Table 1. Overview of all Cation Channels and their Properties Described in Red Blood Cells

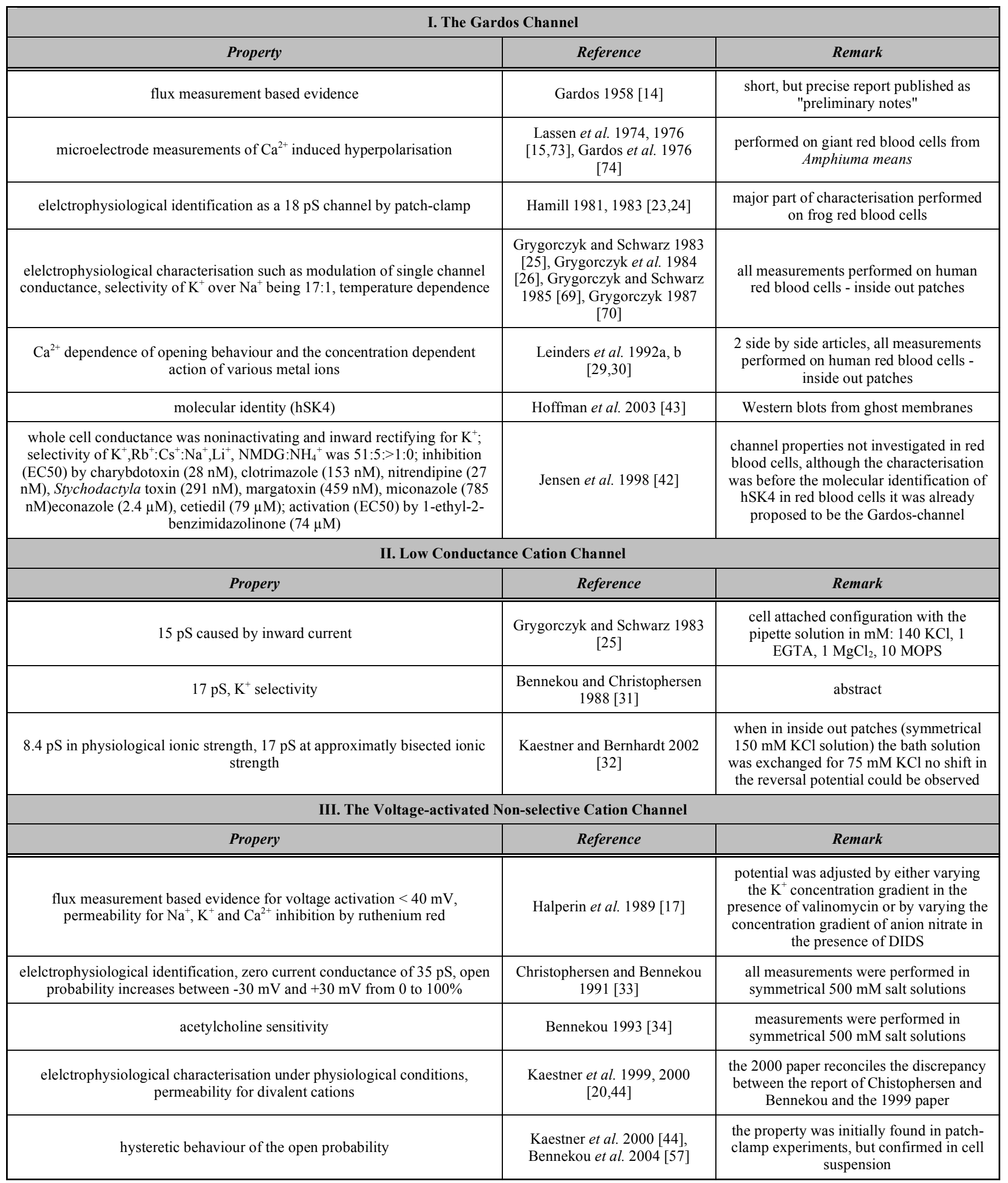


(Table 1) Contd.....

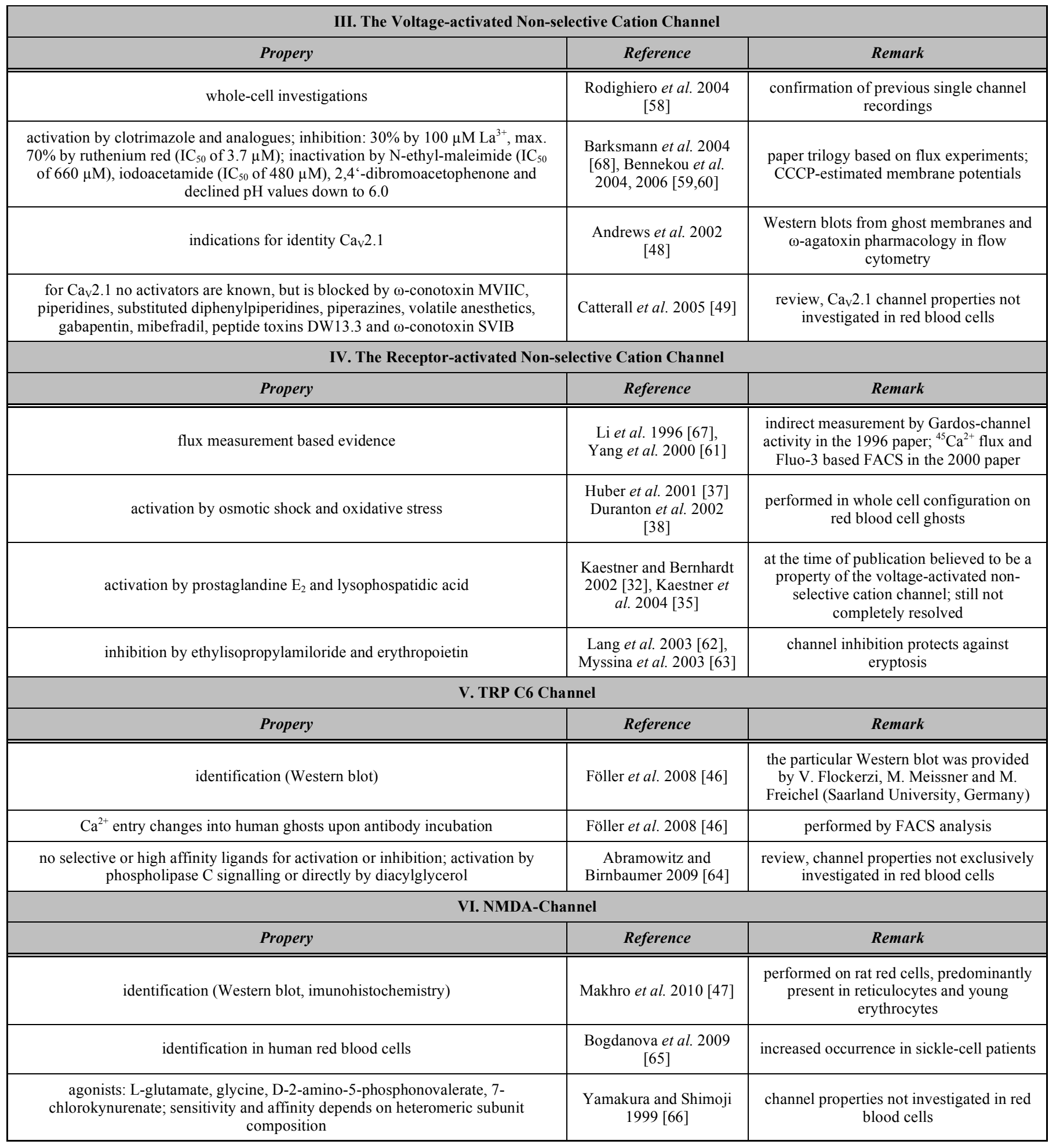

Along with the recordings of the Gardos channel, a small conductance of about $17 \mathrm{pS}$ was observed by Grygorczyk and Schwarz [25] without further characterisation. Bennekou and Christophersen [31] confirmed the finding. Kaestner and Bernhardt [32] reported a channel of a similar conductance, showing no shift in the reversal potential when the $\mathrm{KCl}$ concentration in the bath was bisected. Therefore they concluded to face a proton channel. It is unknown if this channel is identical with the previous reports and an independent confirmation of these results is lacking.

Single channel currents of the voltage-activated nonselective cation channel in human red blood cells were firstly measured by Christophersen and Bennekou [33]. Measurements have been performed in $500 \mathrm{mM}$ salt solutions and as turned-out later on, showed a frequent appearance because it is coupled to an acetylcholine receptor of nicotinic type and 
a contamination of utensils with nicotine due to tobacco smoking in the lab took place [34]. However, the channel could be verified in physiological solutions under agonist free conditions, with an extremely low open probability [20]. The biophysical properties of the channel are nicely displayed by a single current trace depicted in Fig. (2B): The ramp reflects the $\mathrm{I}-\mathrm{V}$ relationship and the channel follows the typical open probability - for a detailed description refer to the figure legend of Fig. (2B).

In 2002 the first electrophysiological report of a receptorlike channel not showing voltage dependent activation behaviour appeared [32]. At the time of publication it was in similarity to the follow-up reports $[35,36]$ believed that this channel is identical with the non-selective voltage-activated cation channel. Whether this is the case or not could still not be resolved completely. As a working hypothesis these reports were grouped in table 1 with other observations by the group of Florian Lang depicting channel activation by osmotic shock and oxidative stress $[37,38]$.

Once the channels are identified on a molecular level (see section 4 , below), a huge number of reports about the channels from other cell types become available. A full coverage of these sources would blast the frame of the present review. Therefore it is just pinpointed to comprehensive reviews (see Table 1, last line for each channel, if applicable).

\section{TOWARDS THE MOLECULAR IDENTITY OF THE CHANNELS}

Identifying the amino-acid blueprint of ion-channels in red blood cells needs a different strategy compared to other cell types, where cloning the protein is the method of choice. Looking at the recent work of proteomics in red blood cells approximately 150 membrane proteins were identified [39, 40]. However, there are basically no obvious candidates for ion channels, although their existence is clearly proved by the patch-clamp technique (compare section 3, above). All identification concepts so far mainly on antibody recognition, either in Western blots or in immunohistochemistry.

As for the Gardos channel at the end of the 1990s a Ca ${ }^{2+}$ activated $\mathrm{K}^{+}$-channel (hSK4) was cloned from, among other tissues, human T-lymphocytes [41] and was assigned to the KCNN4-gene. Shortly afterwards this cloned channel was characterised [42] and from that time the hSK4-channel was the hottest candidate for the Gardos channel, because electrophysiological characterisation as well as the pharmacology of the channel was virtually identical. In 2003 Joe Hoffman and co-workers presented a paper [43] providing further evidence: The Western blots of erythrocyte membranes displayed a clear band for SK4. Additionally, the developmental route was followed from Northern and Western blots of human erythroid progenitor cells to RT-PCR of RNA from reticulocytes also discriminating all other isoforms of the SK-family. These results whipped away all doubts for the hSK4 being identical with the Gardos channel.

For the non-selective cation conductance the situation is slightly more complex. It seems to be clear that the TRPC6 and the NMDA channels are present in red blood cells. For the TRPC6 and the NMDA-channel, the groups of Flockerzi/Freichel and Bogdanowa provided the Western blots, respectively (for references refer to Table 1). However, both channels can not completely account for $\mathrm{Ca}^{2+}$-entry measured by patch-clamp, flow cytometry and fluorescence imaging before $[37,44,45]$. The TRPC6-channel covers just a fraction of the non-selective cation-influx ([46] and own unpublished results). The NMDA-channel is just found in a fraction (subpopulation) of the cells [47]. In conjunction with the $\mathrm{Ca}^{2+}$-permeability a report described Western blots against the $\alpha_{1 \mathrm{~A}}$-subunit of the voltage activated $\mathrm{Ca}_{\mathrm{V}} 2.1$-channel in human red blood cells [48]. From the electrophysiological characterisation it is very hard to compare the data of the voltage-activated non-selective cation channel in red blood cells to $\mathrm{Ca}_{\mathrm{V}} 2.1$-channel recordings in other cells, since these properties are differentially affected by the coexpression level of particular $\beta$-subunits as well as by alternative splicing of the $\alpha_{1 \mathrm{~A}}$-subunit [49]. To clarify this, further investigations are compulsory.

For the low-conductance cation channel it is not even clear whether these are substates of channels covered above or if they have their own identity. No molecular data are available.

\section{RESEARCH PERSPECTIVE}

The future basic research of red blood cells relies - as for most other cell types - on genetic manipulation. This manipulation might be more difficult in red blood cells, since the lack of protein transcription and translation machinery in mature mammalian red blood cells provokes more sophisticated methods. Presently there are two major strategies: (i) manipulation of stem cells and consecutive differentiation into red blood cells as described by Douay and coworkers [50]. A proof of principle that the expression of fluorescent fusion proteins works out in red blood cells was shown by Dickinson and coworkers when using the GFP expression to follow blood flow properties [51], (ii) the use of transgenic animals. Animals having a protein knocked-out or protein over expression, can be investigated independent of their initial purpose of breeding if the method to breed the transgene animal leads to a global and tissue-unspecific gene manipulation. Since the generation of a transgenic mouse is very labour intensive such synergic effects with other research fields can be used. However, within the recent years it became more popular to breed tissue specific and inducible transgenic animals. This may prevent the re-use of transgenic animals in red cell research that have been originally dedicated to other research areas.

Furthermore, the future mode of investigation will be single cell based such as patch-clamp, flow cytometry or live cell imaging, because it enables to identify also smaller subpopulations of cells that can hardly be addressed by measurements of huge populations of cells such as tracer flux analysis.

In that respect it has to be mentioned that these detection methods need to be further exploited. Presently it is e.g. still not possible to measure intracellular calcium concentrations in red blood cells in a quantitative manner. It has been proposed but never performed to solve that problem by fluorescence lifetime imaging [45]. 
Further concepts imply the expression of genetically encoded biosensors (GEBs) that have been proved to be useful tools in many different cell types, either as biomarker $[52,53]$ or as a functional sensor [54, 55]. As for other protein manipulation, the challenges described above lead to the concept of GEB expression in erythroid progenitor cells and consecutive differentiation into red blood cells still containing the sensor.

Independent of the direction of future technological developments, investigations of red blood cell cation channels in health and disease will foster the understanding of blood related pathologies and may provide deeper insight in general cellular physiology [56].

\section{ACKNOWLEDGEMENTS}

I like to thank the Saarland Ministry for Economy and Science for financial support and Prof. Ingolf Bernhardt for proofreading the manuscript.

\section{REFERENCES}

[1] Schatzmann HJ. Why red cells? In: Raess BU, Tunnicliff G, Eds. The Red Cell Membrane A Model for solute Transport. Clifton: Humana Press 1989: pp. 3-17.

[2] Lew VL, Glynn IM, Ellory JC. Net synthesis of ATP by reversal of the sodium pump. Nature 1970; 225: 865-6.

[3] Swammerdam J. Bybel der Natuur. In: Hill J, Ed. The book of nature. London: Bookseller C. G. Seyffert 1737.

[4] Thomas SL, Egee S, Lapaix F, Kaestner L, Staines HM, Ellory JC. Malaria parasite Plasmodium gallinaceum up-regulates host red blood cell channels. FEBS Lett 2001; 500: 45-51.

[5] Lapaix F, Egee S, Gibert L, Decherf G, Thomas SL. ATP-sensitive $\mathrm{K}^{+}$and $\mathrm{Ca}^{2+}$-activated $\mathrm{K}^{+}$channels in lamprey (Petromyzon marinus) red blood cell membrane. Pflugers Arch 2002; 445: 15260 .

[6] Virkki LV, Nikinmaa $\mathrm{M}$. Two distinct $\mathrm{K}^{+}$channels in lamprey (Lampetra fluviatilis) erythrocyte membrane characterized by single channel patch clamp. J Membr Biol 1998; 163: 47-53.

[7] Bennekou P, Christophersen P. Ion Channels. In: Bernhardt I, Ellory JC, Eds. Red cell membrane transport in health and disease. Berlin: Springer Verlag 2003; pp. 139-52.

[8] Abderhalden E. Über den blut kalium gehalt verschiedener säugethiere. Hoppe-Seyler's Zeitschrift für Physiologische Chemie 1889; 25: 65-115.

[9] Bang I. Physiko-chemische verhältnisse der blutkörperchen. Biochemische Zeitschrift 1909; 16: 255-76.

[10] Cohn WE, Cohn ET. Permeability of red corpuscles of the dog to sodium ion. Proc Soc Exp Biol Med 1939; 41: 445-9.

[11] Lew VL, Beaugé L. Passive Cation Fluxes in Red Cell Membranes. In: Giebisch G, Tosteson DC, Ussing HH, Eds. Transport across biological membranes. Vol. II. Berlin: Springer-Verlag 1979; pp. $81-115$.

[12] Ørskov SL. Untersuchungen über den EInfluß von Kohlensäure und Blei auf die Permeabilität der Blutkörperchen für Kalium und Rubidium. Biochem Z 1935; 279: 250-61.

[13] Wilbrandt W. A relation between the permeability of the red cell and its metabolism. Trans Faraday Soc 1937; 33: 956-9.

[14] Gardos G. The function of calcium in the potassium permeability of human erythrocytes. Biochim Biophys Acta 1958; 30: 653-4.

[15] Lassen UV, Pape L, Vestergaard-Bogind B, Bengtson O. Calciumrelated hyperpolarization of the Amphiuma red cell membrane following micropuncture. J Membr Biol 1974; 18: 125-44.

[16] Donlon JA, Rothstein A. The cation permeability of erythrocytes in low ionic strength media of various tinicities. J Membr Biol 1969; 1: 37-52.

[17] Halperin JA, Brugnara C, Tosteson MT, Van Ha T, Tosteson DC. Voltage-activated cation transport in human erythrocytes. Am J Physiol 1989; 257: C986-96.
[18] Richter S, Hamann J, Kummerow D, Bernhardt I. The monovalent cation "leak" transport in human erythrocytes: an electroneutral exchange process. Biophys J 1997; 73: 733-45.

[19] Bernhardt I, Bogdanova AY, Kummerow D, Kiessling K, Hamann J, Ellory JC. Characterization of the $\mathrm{K}^{+}\left(\mathrm{Na}^{+}\right) / \mathrm{H}^{+}$monovalent cation exchanger in the human red blood cell membrane: effects of transport inhibitors. Gen Physiol Biophys 1999; 18: 119-37.

[20] Kaestner L, Bollensdorff C, Bernhardt I. Non-selective voltageactivated cation channel in the human red blood cell membrane. Biochim Biophys Acta 1999; 1417: 9-15.

[21] Bernhardt I, Weiss E, Robinson HC, Wilkins R, Bennekou P Differential effect of HOE642 on two separate monovalent cation transporters in the human red cell membrane. Cell Physiol Biochem 2007; 20: 601-6.

[22] Schwarz W, Grygorczyk R, Hof D. Recording single-channel currents from human red cells. Methods Enzymol 1989; 173: 11221.

[23] Hamill OP. Potassium channel currents in human red blood cells. J Physiol 1981; 319: 97P-8P.

[24] Hamill OP. Potassium and chloride channels in red blood cells. In: Sakmann B, Neher E, Eds. Single-Channel Recording. New York, London: Plenum Press 1983; pp. 451-71.

[25] Grygorczyk R, Schwarz W. Properties of the $\mathrm{Ca}^{2+}$-activated $\mathrm{K}^{+}$ conductance of human red cells as revealed by the patch-clamp technique. Cell Calcium 1983; 4: 499-510.

[26] Grygorczyk R, Schwarz W, Passow H. $\mathrm{Ca}^{2+}$-activated $\mathrm{K}^{+}$channels in human red cells. Comparison of single-channel currents with ion fluxes. Biophys J 1984; 45: 693-8.

[27] Shields M, Grygorczyk R, Fuhrmann GF, Schwarz W, Passow H. Lead-induced activation and inhibition of potassium-selective channels in the human red blood cell. Biochim Biophys Acta 1985; 815: 223-32.

[28] Fuhrmann GF, Schwarz W, Kersten R, Sdun H. Effects of vanadate, menadione and menadione analogs on the $\mathrm{Ca}^{2+}$-activated $\mathrm{K}^{+}$channels in human red cells. Possible relations to membranebound oxidoreductase activity. Biochim Biophys Acta 1985; 820: 223-34.

[29] Leinders T, van Kleef RG, Vijverberg HP. Distinct metal ion binding sites on $\mathrm{Ca}(2+)$-activated $\mathrm{K}^{+}$channels in inside-out patches of human erythrocytes. Biochim Biophys Acta 1992; 1112: 75-82.

[30] Leinders T, van Kleef RG, Vijverberg HP. Single Ca(2+)-activated $\mathrm{K}^{+}$channels in human erythrocytes: $\mathrm{Ca}^{2+}$ dependence of opening frequency but not of open lifetimes. Biochim Biophys Acta 1992; 1112: $67-74$

[31] Bennekou P, Christophersen P. The occurance of a low conductance channel in the human red cell. Acta Physiol Scand 1988; 13: S73.

[32] Kaestner L, Bernhardt I. Ion channels in the human red blood cell membrane: their further investigation and physiological relevance. Bioelectrochemistry 2002; 55: 71-4.

[33] Christophersen P, Bennekou P. Evidence for a voltage-gated, nonselective cation channel in the human red cell membrane. Biochim Biophys Acta 1991; 1065: 103-6.

[34] Bennekou P. The voltage-gated non-selective cation channel from human red cells is sensitive to acetylcholine. Biochim Biophys Acta 1993; 1147: 165-7.

[35] Kaestner L, Tabellion W, Lipp P, Bernhardt I. Prostaglandin E-2 activates channel-mediated calcium entry in human erythrocytes: an indication for a blood clot formation supporting process. Thromb Haemost 2004; 92: 1269-72.

[36] Kaestner L, Tabellion W, Weiss E, Bernhardt I, Lipp P. Calcium imaging of individual erythrocytes: Problems and approaches. Cell Calcium 2006; 39: 13-19.

[37] Huber SM, Gamper N, Lang F. Chloride conductance and volumeregulatory nonselective cation conductance in human red blood cell ghosts. Pflugers Arch 2001; 441: 551-8.

[38] Duranton C, Huber SM, Lang F. Oxidation induces a $\mathrm{Cl}(-)$ dependent cation conductance in human red blood cells. J Physiol 2002; 539: 847-55.

[39] Low TY, Seow TK, Chung MC. Separation of human erythrocyte membrane associated proteins with one-dimensional and twodimensional gel electrophoresis followed by identification with matrix-assisted laser desorption/ionization-time of flight mass spectrometry. Proteomics 2002; 2: 1229-39. 
[40] Bruschi M, Seppi C, Arena S, et al. Proteomic analysis of erythrocyte membranes by soft Immobiline gels combined with differential protein extraction. J Proteome Res 2005; 4: 1304-9.

[41] Logsdon NJ, Kang J, Togo JA, Christian EP, Aiyar J. A novel gene, hKCa4, encodes the calcium-activated potassium channel in human T lymphocytes. J Biol Chem 1997; 272: 32723-6.

[42] Jensen BS, Strobaek D, Christophersen P, et al. Characterization of the cloned human intermediate-conductance $\mathrm{Ca}^{2+}$-activated $\mathrm{K}^{+}$ channel. Am J Physiol 1998; 275: C848-56.

[43] Hoffman JF, Joiner W, Nehrke K, Potapova O, Foye K, Wickrema A. The hSK4 (KCNN4) isoform is the $\mathrm{Ca}^{2+}$-activated $\mathrm{K}^{+}$channel (Gardos channel) in human red blood cells. Proc Natl Acad Sci USA 2003; 100: 7366-71.

[44] Kaestner L, Christophersen P, Bernhardt I, Bennekou P. The nonselective voltage-activated cation channel in the human red blood cell membrane: reconciliation between two conflicting reports and further characterisation. Bioelectrochemistry 2000; 52: 117-25.

[45] Kaestner L, Tabellion W, Weiss E, Bernhardt I, Lipp P. Calcium imaging of individual erythrocytes: problems and approaches. Cell Calcium 2006; 39: 13-19.

[46] Foller M, Kasinathan RS, Koka S, et al. TRPC6 contributes to the $\mathrm{Ca}(2+)$ leak of human erythrocytes. Cell Physiol Biochem 2008; 21: 183-92.

[47] Makhro A, Wang J, Vogel J, et al. Functional NMDA receptors in mammalian erythrocytes. Am J Physiol Cell Physiol 2010; 298: C1315-25.

[48] Andrews DA, Yang L, Low PS. Phorbol ester stimulates a protein kinase $\mathrm{C}$-mediated agatoxin-TK-sensitive calcium permeability pathway in human red blood cells. Blood 2002; 100: 3392-9.

[49] Catterall WA, Perez-Reyes E, Snutch TP, Striessnig J. International Union of Pharmacology. XLVIII. Nomenclature and structurefunction relationships of voltage-gated calcium channels. Pharmacol Rev 2005; 57: 411-25.

[50] Giarratana MC, Kobari L, Lapillonne H, et al. Ex vivo generation of fully mature human red blood cells from hematopoietic stem cells. Nat Biotechnol 2005; 23: 69-74.

[51] Jones EA, Baron MH, Fraser SE, Dickinson ME. Measuring hemodynamic changes during mammalian development. Am J Physiol Heart Circ Physiol 2004; 287: H1561-9.

[52] Scheller N, Resa-Infante P, de la Luna S, et al. Identification of PatL1, a human homolog to yeast P body component Pat1. Biochim Biophys Acta 2007; 1773: 1786-92.

[53] Kaestner L, Scholz A, Hammer K, Vecerdea A, Ruppenthal S, Lipp $P$. Isolation and genetic manipulation of adult cardiac myocytes for confocal imaging. J Vis Exp 2009; 31: http://www.jove.com/index/ Details.stp?ID $=1433$.

[54] Viero C, Kraushaar U, Ruppenthal S, Kaestner L, Lipp P. A primary culture system for sustained expression of a calcium sensor in preserved adult rat ventricular myocytes. Cell Calcium 2008; 43 : 59-71.

[55] Kaestner L, Ruppenthal S, Schwarz S, Scholz A, Lipp P. Concepts for optical high content screens of excitable primary isolated cells for molecular imaging. In: Licha K, Lin CP, Eds. SPIE biomedical optics. Munich: SPIE 2009; pp. 737-45.

[56] Mohandas N, Gallagher PG. Red cell membrane: past, present, and future. Blood 2008; 112: 3939-48.

[57] Bennekou P, Barksmann TL, Jensen LR, Kristensen BI, Christophersen P. Voltage activation and hysteresis of the non- selective voltage-dependent channel in the intact human red cell. Bioelectrochemistry 2004; 62: 181-5.

[58] Rodighiero S, De Simoni A, Formenti A. The voltage-dependent nonselective cation current in human red blood cells studied by means of whole-cell and nystatin-perforated patch-clamp techniques. Biochim Biophys Acta 2004; 1660: 164-70.

[59] Bennekou P, Barksmann TL, Kristensen BI, Jensen LR, Christophersen P. Pharmacology of the human red cell voltagedependent cation channel. Part II: inactivation and blocking. Blood Cells Mol Dis 2004; 33: 356-61.

[60] Bennekou P, Barksmann TL, Christophersen P, Kristensen BI. The human red cell voltage-dependent cation channel. Part III: Distribution homogeneity and $\mathrm{pH}$ dependence. Blood Cells Mol Dis 2006; 36: 10-14.

[61] Yang L, Andrews DA, Low PS. Lysophosphatidic acid opens a $\mathrm{Ca}(++)$ channel in human erythrocytes. Blood 2000; 95: 2420-5.

[62] Lang KS, Myssina S, Tanneur V, Wieder T, Huber SM, Lang F, Duranton C. Inhibition of erythrocyte cation channels and apoptosis by ethylisopropylamiloride. Naunyn Schmiedebergs Arch Pharmacol 2003; 367: 391-6.

[63] Myssina S, Huber SM, Birka C, Lang PA, Lang KS, Friedrich B, Risler $\mathrm{T}$, Wieder $\mathrm{T}$, Lang $\mathrm{F}$. Inhibition of erythrocyte cation channels by erythropoietin. J Am Soc Nephrol 2003; 14: 2750-7.

[64] Abramowitz J, Birnbaumer L. Physiology and pathophysiology of canonical transient receptor potential channels. FASEB J 2009; 23: 297-328.

[65] Bogdanova A, Makhro A, Goede J, et al. NMDA receptors in mammalien erythrocytes. Clin Biochem 2009; 42: 1858-9.

[66] Yamakura T, Shimoji K. Subunit- and site-specific pharmacology of the NMDA receptor channel. Prog Neurobiol 1999; 59: 279-98.

[67] Li Q, Jungmann V, Kiyatkin A, Low PS. Prostaglandin E2 stimulates a $\mathrm{Ca}^{2+}$-dependent $\mathrm{K}^{+}$channel in human erythrocytes and alters cell volume and filterability. J Biol Chem 1996; 271: 186516.

[68] Barksmann TL, Kristensen BI, Christophersen P, Bennekou P. Pharmacology of the human red cell voltage-dependent cation channel; Part I. Activation by clotrimazole and analogues. Blood Cells Mol Dis 2004; 32: 384-8.

[69] Grygorczyk R, Schwarz W. $\mathrm{Ca}^{2+}$-activated $\mathrm{K}^{+}$permeability in human erythrocytes: modulation of single-channel events. Eur Biophys J 1985; 12: 57-65.

[70] Grygorczyk R. Temperature dependence of $\mathrm{Ca}^{2+}$-activated $\mathrm{K}^{+}$ currents in the membrane of human erythrocytes. Biochim Biophys Acta 1987; 902: 159-68.

[71] Kaestner L. Passive elektrogene Transportprozesse durch die Membran von Humanerythrozyten und Erythrozyten von gesunden und Malaria-infizierten Hühnern. Berlin: Logos Verlag 2001.

[72] Bernhardt I, Erdmann A, Glaser R, Reichmann G, Bleiber R. Influence of lipid composition on passive ion transport of erythrocytes. In: Klein RA, Schmitz B, Eds. Topics in lipid research fram structural elucidation to biological function. London: The Royal Society of Chemistry 1986; pp. 243-8.

[73] Lassen UV, Pape L, Vestergaard-Bogind B. Effect of calcium on the membrane potential of Amphiuma red cells. J Membr Biol 1976; 26: 51-70.

[74] Gardos G, Lassen UV, Pape L. Effect of antihistamines and chlorpromazine on the calcium-induced hyperpolarization of the Amphiuma red cell membrane. Biochim Biophys Acta 1976; 448: 599-606. 